\title{
Electrorheology of Suspensions of Aluminum Borate Whiskers Bonded with Poly(Ethylene Glycol)
}

\author{
Yuji HiRose ${ }^{\dagger}$ and Yasufumi OTsubo \\ Department of Urban Environment Systems, Graduate School of Engineering, Chiba University \\ 1-33, Yayoi-cho, Inage-ku, Chiba-shi, 263-8522, Japan
}

\begin{abstract}
We prepared aluminum borate whiskers/PEG complex powder (PEG $0.5 \sim 5.0 \mathrm{wt} \%$ ) by freeze-drying aqueous solutions of PEG with whiskers and studied ER properties of suspensions (contains $10 \mathrm{wt} \%$ powder). When the external electric field was not applied, the shear stress of complex powder (PEG $0.5 \sim 1.5 \mathrm{wt} \%$ ) suspensions at low shear rate was higher than that of neat whisker suspensions. The suspension of whiskers with $1.0 \mathrm{wt} \%$ PEG showed higher shear stress than that of neat whiskers under dc electric field. However, whiskers with $0.5 \mathrm{wt} \%$ PEG showed weaker ER effect than neat whiskers. When electric field is applied to neat whisker suspensions, whiskers comprise highly branched chains between electrodes. It is assumed that attached PEG alters the structure of whisker chains but this effect is weaker than that of engagement of whiskers in case of $1.0 \mathrm{wt} \%$ PEG. In addition, ER effect was not enhanced when whiskers and PEG powder are added in silicon oil severally. Thus, bonding whiskers with PEG by freeze-drying is effective to enhance the ER effect of whisker suspensions.
\end{abstract}

Key Words: Electrorheology / Poly(ethylene glycol) / Suspension / Composite particles / Whiskers

\section{ポリエチレングリコールにより接着したホウ酸アルミニウムウィスカー 分散系のエレクトロレオロジー}

\author{
廣瀬 裕二 ${ }^{\dagger}$, 大坪 泰文 \\ （原稿受理：2014 年 9 月 3 日）
}

\section{1. はじめに}

微粒子分散系 ER 流体は実用化のためのデバイス開発 ${ }^{1)} の$ ほか, 性能向上やメカニズム解明を目指して複合材料をは じめとしたさまざまな試料の研究が行われている。例えば モノマーにER 効果を有するナノサイズの無機材料粒子（水 酸化チタンと二酸化チタンの混合物）を加えて水中で懸濁 重合することにより, 無機材料がマイクロサイズのポリマー 芯材の表面を覆う複合粒子が作られている。この粒子は密 度の大きな無機材料の重力沈降が抑制され高い分散安定性 を有する. ${ }^{2}$ またポリエチレングリコール (PEG) に微量のポ リビニルアルコール (PVA) をブレンドした粒子の分散系が, 純 PVA 粒子分散系が ER 効果を示さないにもかかわらず純 PEG 分散系より高い ER 効果を示すことが確認されている."

本研究ではホウ酸アルミニウムのウイスカー (針状粒子) ${ }^{4)}$ をPEG 水溶液中に分散させて凍結乾燥させるという簡便

\footnotetext{
$\uparrow$ To whom correspondence should be addressed 千葉大学大学院工学研究科都市環境システム学科

T263-8522 千葉県千葉市稲毛区弥生町 1-33

E-mail: hirose@tu.chiba-u.ac.jp
}

な方法によって複合材料を調整し，この粒子をシリコンオ イル中に分散させた系の ER 効果を調べた。 ウィスカー ${ }^{4)}$, $\mathrm{PEG}^{3,5}$ ともにその微粒子分散系はER効果を示す. ウィスカー がPEGで接着されることにより突起の付いた粒子が形成さ れ，粒子同士が近づきにくくなるために排除体積が増大す るほか, 電場印加時および流動時に歯車がかみ合うように 突起がぶつかることにより ER 効果が大きくなることが期待 される。

\section{2. 実 験}

ホウ酸アルミニウムウィスカーは四国化成(侏)製のアルボ レックス M-20（直径 $0.5 \sim 1.0 \mu \mathrm{m}$, 長さ $10 \sim 30 \mu \mathrm{m}$ ）を, PEG は和光純薬工業(株)のポリエチレングリコール 4,000 (平均分 子量 3,000) を用いた. PEG を蒸留水に溶かし, ウイスカー を加え振り混ぜ分散させたものを急速冷凍した後凍結乾燥 を行い, 得られた固体を $150 \mu \mathrm{m}$ メッシュのふるいにかけた。 ふるい分けられなかった試料は乳棒で軽く粉砕した後に再 度同じふるいにかけた。この粒子をシリコンオイル（GE 東 芝シリコーン TSF451-100）中に粒子含率 $10 \mathrm{wt} \%$ となるよう に加え, ミックスローターを用いて回転数 $40 \mathrm{rpm}$ で 24 時間 
以上撹拌した. 応力制御型レオメーター (Haake RS-100) に平 行平板（直径 $35 \mathrm{~mm}$ ) を間隔 $1.5 \mathrm{~mm}$ で取り付け試料をはさ み, 上方が陽極, 下方が㓌極となるよう直流電場を印加した。 一定のせん断速度で上部平板を回転させ，30秒後にほぼ一 定となったせん断応力の值をデータとして取り, せん断速 度を上昇させて同様の測定を繰り返した。

\section{3. 結果と考察}

Fig. 1 は PEG を $1.0 \mathrm{wt} \%$ を含むウイスカー複合粒子のデジ 夕ル顕微鏡写真である. ウイスカーを入れない PEG を粉砕 した粒子の表面はなめらかであるのに対し ${ }^{5)}$, この粒子の周 囲には多数の針状ウィスカー粒子が付着している。電場を 印加していない状態における各分散系のせん断応力のせん 断速度依存性を Fig. 2 に示す. PEG $0.5 \sim 1.5 \mathrm{wt} \%$ を含む粒子 では低せん断速度域で応力が増大し, 平坦部を示す傾向が 見られた.PEGに取り込まれたウィスカーの突起が別のウィ スカーにひっかかることで弱い凝集構造を形成して流動抵 抗が上昇する一方, せん断速度が高くなると凝集構造が破壊 されて見かけ粘度が低下したと考えられる。 またPEGの多 い粒子では多数のウイスカーがPEG 内部に取り込まれ, 突 起の平均長が短くなるため凝集効果が小さくなったと推測 される。

Fig. 3 は $1.0 \mathrm{kV} / \mathrm{mm}$ の直流電場を印加した際の各分散系の 流動曲線である。無電場下の低せん断速度域では PEG 0.5, $1.0 \mathrm{wt} \%$ の粒子はどちらも純ウイスカーより高いせん断応力 を示したのに対し, 電場下の降伏応力は PEG 0.5 wt \% では純 ウイスカー系より小さく, PEG $1.0 \mathrm{wt} \%$ では逆に大きくなっ た.つまり電場下では分散質の凝集構造の形成とは異なる 効果が流動性に影響を与えたと考えられる，PEGを含まな

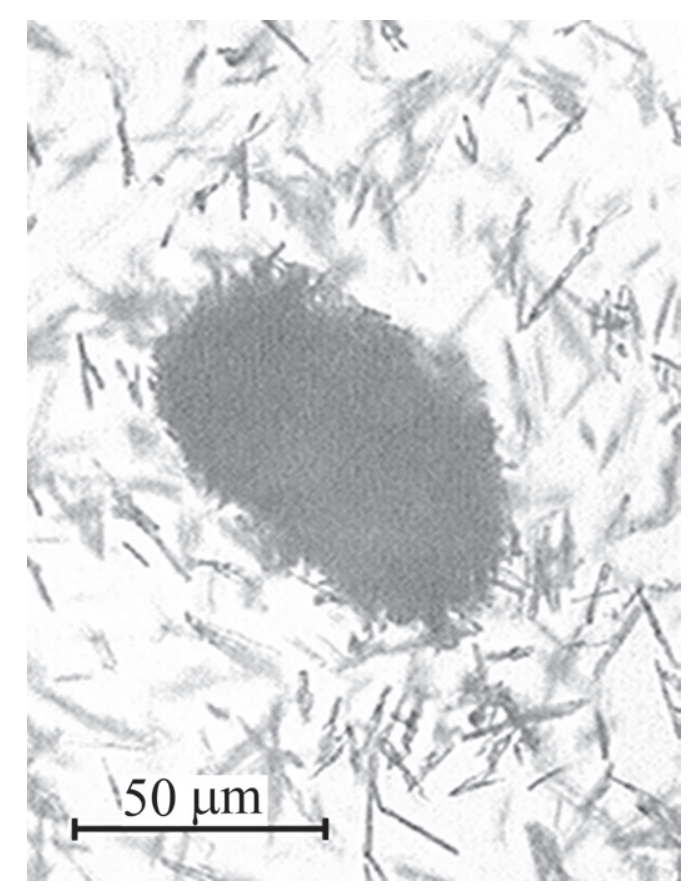

Fig. 1. A micrograph of a composite particle of aluminum borate whiskers (99 $\mathrm{wt} \%)$ and PEG (1 wt\%).
いホウ酸アルミニウムウィスカー分散系に直流電場を印加 するとウイスカーが枝分かれをした配置を取ったカラム構 造が電極間に形成される. の粒子が陰極側に凝集し, 一部の粒子のみが電極間のカラ ム形成に寄与する. ${ }^{3}$ ウイスカーが PEGによって接着される ことによって規則的なカラムの構造に欠陥が生じたり, PEG とともに陰極側に凝集したりすることで ER 効果は弱くなる と予想される。測定結果より PEG $0.5 \mathrm{wt} \%$ の粒子ではこれら の影響が大きいものの, PEG $1.0 \mathrm{wt} \%$ のときはウイスカーが 形成する粒子の突起がかみ合う効果が顕著に表れたと考え られる。

Fig. 4 は PEG $1.0 \mathrm{wt} \%$ を含むウイスカー粒子 $1.0 \mathrm{wt} \%$ 分散 系に $0.5 \mathrm{kV} / \mathrm{mm}$ の電場を水平方向に印加した際の顕微鏡写真

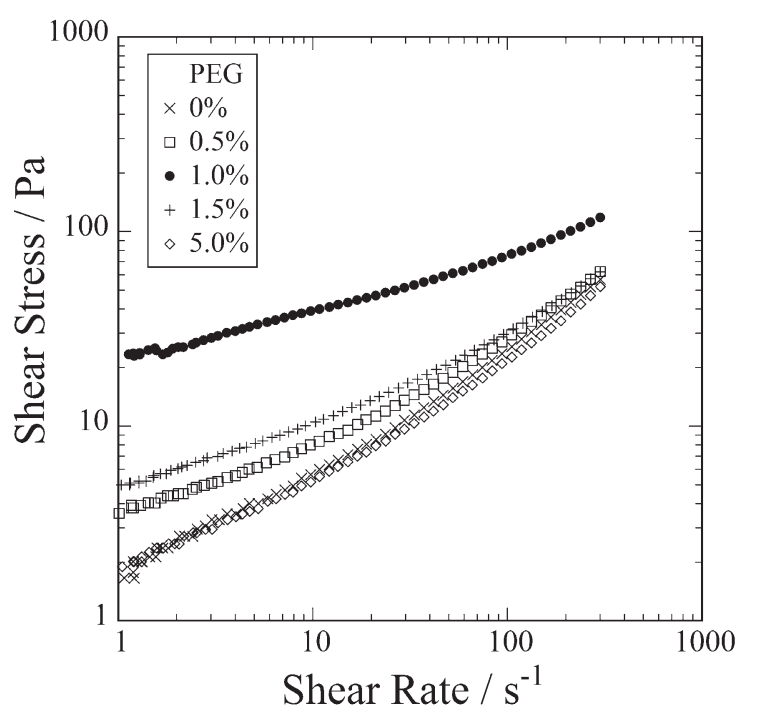

Fig. 2. Shear rate dependence of shear stress for aluminum borate whisker/PEG composite particle (10 wt\%) suspensions at $298 \mathrm{~K}$.

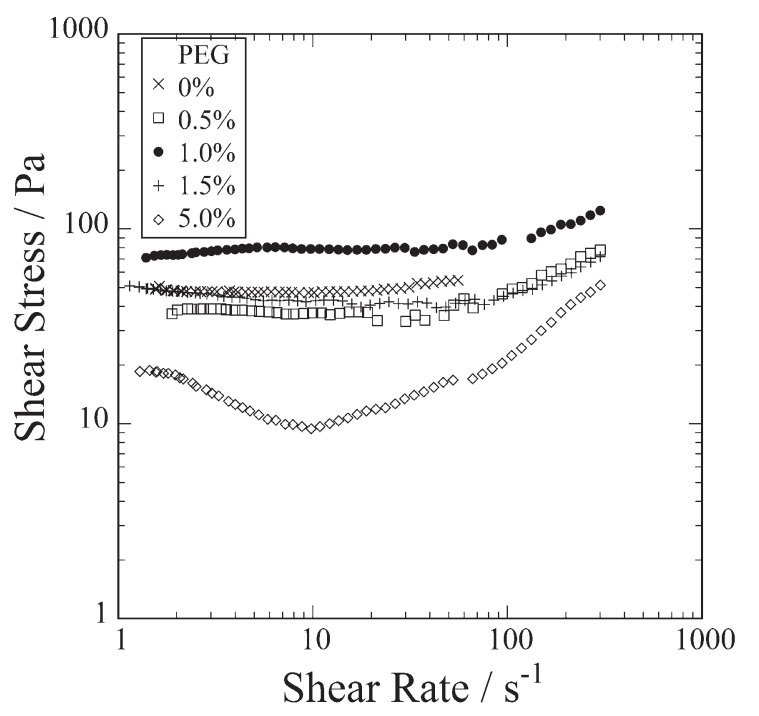

Fig. 3. Shear rate dependence of shear stress for aluminum borate whisker/PEG composite particle (10 wt $\%$ ) suspensions under $\mathrm{dc}$ electric field $(1.0 \mathrm{kV} / \mathrm{mm})$ at $298 \mathrm{~K}$. 


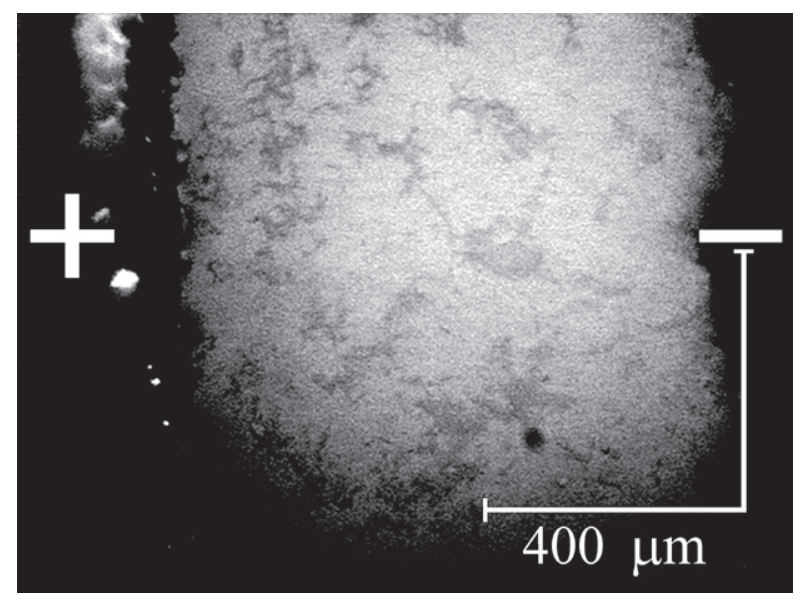

Fig. 4. A microphotograph of aluminum borate whisker/PEG $=99 / 1$ composite particle $(1.0 \mathrm{wt} \%)$ suspension under dc electric field $(1.0 \mathrm{kV} / \mathrm{mm})$ at $298 \mathrm{~K}$.

を，過去に使用した ${ }^{6)}$ 透明電極を用いた器具により鉛直方 向から撮影したものである。このとき肉眼で電極間に白い 凝集構造が現れたことが確認できた。Fig. 4 では倍率を低く したため細いウィスカーの一本一本は写っていないものの 数十 $\mu \mathrm{m}$ の $\mathrm{PEG}$ 粒子が電極の間にバラバラに存在しており, ウィスカーのカラム構造の中に PEG が取り込まれているこ とが確認できた

また Fig. 3 において, PEG $5.0 \mathrm{wt} \%$ の粒子では $10 \mathrm{~s}^{-1}$ 以下 においてせん断速度の増加に伴い応力が低下した。この現 象は電場強度や電極間距離を変えた場合でも見られた。鎖 状構造が破壊されると粒子は再度鎖状構造を作ろうとする が, 再形成が起こりにくい場合は流動が速くなることで流動 抵抗が大きく低下し流動曲線の傾きが負になることがある。? PEG 1.5 wt \% でもわずかに傾きが負になったことから, 多く のPEG を加えたことでウイスカーが取り込まれカラムを形 成する粒子が減り応力低下のほか流動曲線の傾きが負にな る現象が見られたと考えられる。

このほか純 PEG 粒子と純ウイスカー粒子を分散系の全質 量に対しそれぞれ $0.1 \mathrm{wt} \%, 9.9 \mathrm{wt} \%$ シリコンオイルに加え
た系の電場強度 $1.0 \mathrm{kV} / \mathrm{mm}$ における流動性を調べたところ, 純ウイスカー $10 \mathrm{wt} \%$ 分散系とあまり変わらなかった。同組 成の凍結乾燥させたものでは降伏応力が増大したことから， 凍結乾燥によるウイスカー同士が歯車のようにかみ合う効 果がその ER 効果を向上させたことが分かった.

\section{4. まとめ}

ホウ酸アルミニウムウイスカーが Fig. 1 のように PEGの 粒子の周囲を覆うことでその表面に多数の細長い突起がで き，歯車のようにかみ合って電場印加時に形成されるカラ ムが強化されると予想される。その一方でこのウィスカー 分散系は PEG を含まない場合，電場下では枝分かれした特 異な構造のカラムを形成することにより比較的高い ER 効果

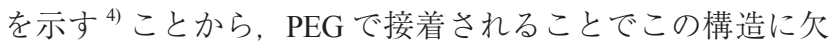
陥が生じることが懸念される.

PEG $1.0 \mathrm{wt} \%$ の粒子ではこの構造欠陥の影響よりも突起に よる電場印加時の突起同士のかみ合いの効果が強く表れた. $1.0 \mathrm{wt} \%$ より PEG が少ない場合は PEG が絡んでいないウィ スカーの割合が大きくなり，逆に PEGが多い場合はウィス カーが PEG 結晶の中により取り込まれ突起が短くなりかみ 合う効果が小さくなり, さらに電場下では PEGの一部が陰 極側に凝集する作用によって無電場下，電場下の双方におい て応力が低下したと考えられる。つまりウィスカーと PEG の組成を調整すれば凍結乾燥によりウィスカーを接着する という簡便な手法でその分散系の ER 効果を向上させること が可能であるということが分かった.

\section{REFERENCES}

1) Furusho J, Haraguchi M, J Rob Mech, 26, 302 (2014).

2) Otsubo Y, Edamura K, J Colloid Interface Sci, 168, 230 (1994).

3) Hirose Y, Otsubo Y, Colloids Surf A, 317, 438 (2008).

4) Tsuda K, Takeda Y, Ogura H, Otsubo Y, Colloids Surf A, 299, 262 (2007).

5) Hirose Y, Otsubo Y, Nihon Reoroji Gakkaishi, 38, 61 (2010).

6) Hirose Y, Otsubo Y, Colloids Surf A, 414, 486 (2012). 